\title{
LETRAMENTOS LITERÁRIOS E TRANSLINGUAGEM ENTRE AS RUAS E AS ESCOLAS DO SUL GLOBAL: O SLAM INTERESCOLAR COMO PRÁTICA ENATIVO-PERFORMATIVA DECOLONIAL
}

\author{
LITERARY LITERACIES AND TRANSLANGUAGING BETWEEN THE STREETS AND THE \\ SCHOOLS FROM THE GLOBAL SOUTH: THE INTERSCHOOL SLAM AS AN \\ ENACTIVE-PERFORMATIVE AND DECOLONIAL PRACTICE
}

\author{
Marcella dos Santos Abreu* \\ Cláudia Hilsdorf Rocha** \\ Ruberval Franco Maciel ${ }^{\star * *}$
}

\begin{abstract}
RESUMO
Neste artigo, pretendemos visibilizar os slams vivenciados "das ruas para as escolas, das escolas para as ruas" como letramentos literários que promovem, entre as juventudes do Sul Global, espaços translíngues potencialmente criativos, críticos e transformativos. Partindo do grito de luta do projeto Slam Interescolar SP, destacamos os antecedentes e a trajetória da iniciativa organizada, desde 2015, pelo coletivo paulistano Slam da Guilhermina. Posteriormente, exploramos entendimentos sobre translinguagem e decolonialidade, lentes pelas quais vemos emergir as sensibilidades de mundo que desafiam práticas monoglóssicas e narrativas hegemônicas em batalhas poéticas travadas desde o chão das escolas. Identificamos tais subversões na análise do poema Géputáre tenetehára, da então estudante de Ensino Médio Franciele Evangelista Apolinário, durante a etapa final do projeto Slam Interescolar SP 2020 - edição online. Destacamos os aspectos poético-literários, aos quais aproximamos dimensões da abordagem translíngue enativo-performativa, para apontarmos a potência de linguagens, histórias e culturas como experiências estéticas transformadoras dos slams inseridos no contexto escolar paulista. Por fim, consideramos que essas vivências podem potencializar a presença de gretas e semeaduras das quais emergem gritos de resistência entre os jovens slammers desse território. Palavras-chave: letramentos literários; Slam Interescolar; translinguagem; práticas enativo-performativas; decolonialidade.
\end{abstract}

\section{ABSTRACT}

In this paper, we intend to make visible the slams experienced "from the streets to the schools, from the schools to the streets" as literary literacies that promote, among the youth of the Global South, potentially creative, critical and transformative translingual spaces. Based on the struggle cry of the Slam Interescolar SP project, we highlight the history and trajectory of the initiative, organized since 2015 by the São Paulo collective Slam da Guilhermina. Subsequently, we explore understandings of translanguaging and decoloniality, lenses through which we see emerging world sensibilities that challenge monoglossic practices and hegemonic narratives in their poetic battles fought from the ground of schools. We identified such subversions in the analysis of the poem Gé putáre tenetehára, by the then high school student Franciele Evangelista Apolinário, during the final stage of the Slam Interescolar SP 2020 project - online edition. We highlight the poetic-literary aspects, to which we approach dimensions of the enactiveperformative translingual approach, in order to point out the power of languages, histories and cultures as transforming aesthetic experiences of the slams inserted in the São Paulo school context. Finally, we believe that these experiences can enhance the presence of cracks and sowings from which cries of resistance emerge among the young slammers in this territory. Keywords: literary literacies; Interschool Slam; translanguaging; enactive-performative practices; decoloniality.

\section{INTRODUÇÃO}

"Das ruas para as escolas, das escolas para as ruas" é o grito que ecoa entre estudantes da educação básica paulista quando participam do Slam Interescolar, projeto organizado desde 2015 pelo coletivo Slam da Guilhermina (ASSUNÇÃO; JESUS; SANTOS, 2021). Dessa iniciativa emergem práticas de letramentos literários (NEVES, 2021a) que potencializam a subversão, não apenas dos modos hegemônicos de compreensão, produção, circulação e recepção da literatura, mas também de lógicas normalizantes e de ideologias monolíngues que autoritariamente transitam entre as comunidades escolares e seus territórios localizados no Sul Global (SANTOS, 2007).

\footnotetext{
* Universidade Federal do ABC (UFABC), Santo André, SP, Brasil. marcella.galache@gmail.com Orcid: https://orcid.org/0000-0003-1293-4786

** Universidade Estadual de Campinas (Unicamp), Campinas, SP, Brasil. claudiahrocha@gmail.com Orcid: https://orcid.org/0000-0001-9717-2375

***Universidade Estadual de Mato Grosso do Sul (UEMS), Dourados, MS, Brasil. ruberval.maciel@gmail.com Orcid: https://orcid.org/0000-0003-0373-1047
} 
Tendo como objetivo visibilizar tal potência translíngue e decolonial (GARCÍA; ALVIS, 2019) do slam nas e entre as escolas para a criação de espaços sociais, críticos e transformadores (LI WEI, 2011), destacamos o poema Gé putáre tenetehára, que foi apresentado pela então estudante de Ensino Médio Franciele Evangelista Apolinário1, durante a etapa final do Slam Interescolar SP 2020 - edição online (SLAM DA GUILHERMINA, 2020).

Situamos nossa discussão no campo da Linguística Aplicada Indisciplinar (MOITA LOPES, 2006, 2010), ou seja, em um campo de estudos caracterizado, desde muito, como transdisciplinar (CELANI, 1992) e transgressivo (PENNYCOOK, 2006), na medida em que procura criticamente responder às complexas demandas da contemporaneidade (FREIRE, 2020), desafiando fronteiras disciplinares rigidamente impostas e enfrentando paradigmas há muito consagrados (FABRÍCIO, 2006).

Partindo de tal lugar, pretendemos explorar o potencial heterodiscursivo (BAKHTIN, 2015) de práticas desobedientes, indisciplinares e transformativas vivenciadas pelas juventudes. Nesse âmbito, consideramos, especialmente, estudantes das escolas públicas periféricas que, entre 2019 e 2020, representaram a totalidade dos participantes do Slam Interescolar. Tais jovens fazem emergir, com sua poesia falada e sua gramática do cotidiano (EVARISTO, 2019), não apenas palavras, mas também sensibilidades de mundo (MIGNOLO, 2017) que atravessam seus corpos racializados, feminizados e vulnerabilizados socioeconomicamente.

Para desafiarmos esses marcadores da diferença mantidos na matriz da colonialidade, são necessárias lentes decoloniais (MIGNOLO, 2000; MALDONADO-TORRES, 2018), as quais aqui alinhamos à translinguagem como prática cotidiana de resistência em contextos de luta (CANAGARAJAH, 2017; MAZZAFERRO, 2018; SEVERO; ABDELHAY; MAKONI, 2020).

Nesse viés, a translinguagem apresenta-se como um projeto ontológico que reconhece a natureza enativoperformativa do processo integrativo de construção de sentidos (GARCÍA, 2020a; ADEN; ESCHENAUER, 2020), demandando desobediência epistemológica (MIGNOLO, 2017). A experiência estética revela-se, assim, como prática crítica e criativa de linguagens e letramentos (GARCÍA, 2020a) que, situada no tempo-espaço, realiza-se nas fronteiras, como acontecimento do existir (BAKHTIN, 2017), desafiando as ideologias monolíngues e a ordem social hegemônica.

Tal perspectiva permite-nos acessar as experiências de formação, preparação e participação no slam realizado com/entre as comunidades escolares como experiências corporificadas de reexistência (SOUZA, 2011), performadas entre mundos translíngues (GARCÍA, 2020a).

O Slam Interescolar é descrito por seus organizadores como um processo que envolve desde a formação nas escolas, com poetas da cena do slam, à participação efetiva de estudantes como slammers (poetas), slammasters (apresentadores), produtores de cartazes, zines e placas de notas dos jurados (AÇÃO EDUCATIVA, 2020).

Nesses gestos, vislumbram-se práticas de letramentos literários atravessadas por temáticas como sexismo, política, racismo, depressão e suicídio. Além disso, a orientação translíngue desses slams, tonalizada por uma ótica decolonial, permite a emergência de sensibilidades alternativas de mundo, como a experiência estética de Franciele Apolinário, com narrativas que desafiam o antropoceno (KRENAK, 2020).

Perante a necessidade de romper com discursos de censura e opressão, ressaltamos a potência de ações semelhantes às do citado projeto para a promoção de uma educação libertária (FREIRE, [1992] 2018), comprometida com a expansão de repertórios vivenciais (MEGALE; LIBERALI, 2020) e com o trânsito desobediente de letramentos, corpos e pedagogias decoloniais nas fronteiras de ruas e escolas, as gretas do sistema de guerra-morte mundial (WALSH, 2017, 2019).

Nessas bases, este artigo pretende desenvolver suas ideias a partir do histórico do projeto Slam Interescolar, seguido pela apresentação das noções que sustentam a orientação translíngue e decolonial. Nesse viés, serão tecidas considerações sobre uma abordagem educacional translíngue enativo-performativa, cujos parâmetros de análise serão fundamentais para a discussão sobre o slam Gé putáre tenetebára.

\section{SLAM INTERESCOLAR: ANTECEDENTES DE UMA PEDAGOGIA ENTRE GRETAS E GRITOS VIÁVEIS}

Conhecemos os antecedentes e a trajetória do Slam Interescolar SP, quando nos debruçarmos sobre entrevistas e publicações recentes acerca da história desse projeto, que tem como narradores/as Cristina Assunção, Emerson Alcalde

1. Em 2020, Franciele tinha 17 anos e cursava o $3^{\circ}$ ano do Ensino Médio. Recebemos a transcrição de seu poema graças à mediação de Uillian Chapéu, um dos organizadores do Slam Interescolar, que nos apresentou à professora da slammer, Carla Vizu Tavares, da Escola Estadual Profa. Suely Maria Cação, de Indaiatuba-SP. Agradecemos a todos/as a colaboração e ressaltamos que a estudante nos autorizou, por meio de um Termo de Consentimento Livre e Esclarecido (TCLE), a fazermos uso das imagens, do poema e dos depoimentos que aqui serão apreciados. 
e Uillian Santos (conhecido como Chapéu). Trata-se de membros do coletivo Slam da Guilhermina que, desde 2012, realizam mensalmente um campeonato de poesia falada em uma praça a céu aberto e anexa à estação GuilherminaEsperança do metrô, na zona leste da cidade de São Paulo (ASSUNÇÃO; JESUS; SANTOS, 2021, p. 19).

Nesses registros, consta que Emerson, às vésperas de ser vice-campeão da copa do mundo de slam de 2014 na França, ficara impressionado com a descoberta de um evento paralelo: o slam interescolar parisiense. Cristina o acompanhava na viagem e ambos apreciaram esta competição organizada no mesmo formato daquele mundial, mas com a participação de slammers de 7 a 11 anos de idade, incentivados/as pela animada torcida de seus/suas colegas que chegavam ao teatro Belleville em vários ônibus escolares (AÇÃO EDUCATIVA, 2020).

No recém-publicado livro Das ruas para as escolas, das escolas para as ruas: Slam Interescolar (ASSUNÇÃO; JESUS; SANTOS, 2021), Alcalde detalhou como o encontro com aquele cenário o deslocara imediatamente a representações sobre a realidade de crianças e jovens no Brasil:

Me espanto com a empolgação das crianças francesas em aguardar ansiosamente por um campeonato de poesia falada. Penso que
isso seria normal no meu país caso fosse um torneio de futebol (...), mas uma Copa de poesia falada... Eu não conseguia imaginar os
meninos e as meninas da quebrada calados em um espaço cheio de gente, quem diria competindo em uma atividade que envolve corpo
e palavra. Realmente, na França é outros 500 . As crianças fazem barulho no teatro, querem ficar de pé, exibem seus cartazes com o
nome do/a poeta competidor/a e assim provocam os/as demais. É anunciado o nome da primeira criança poeta, que sobe no palco,
pega o microfone, e logo o silêncio e a concentração imperam. Noto que essas crianças poetas até que não são tímidas, afinal, estão
declamando seus poemas para diversas outras crianças, de outras escolas, e estão sendo avaliadas por pessoas adultas que nem sequer
conhecem (JESUS, 2021, p. 14).

Provocado por essa experiência vivenciada em Paris, o casal retornou aos 500 de cá e propôs aos demais membros do Slam da Guilhermina a organização de algo semelhante com as escolas paulistanas. Começaram pelo colégio La Salle, instituição de ensino privada da zona leste de São Paulo, onde Cristina era professora de História. Em 2015, ela propôs a realização do slam por ocasião da feira do livro e, a partir dessa oportunidade, a atividade se tornaria mensal (AÇÃO EDUCATIVA, 2020).

As batalhas intersalas realizadas naquela comunidade escolar, somadas a oficinas de escrita e competições promovidas por Alcalde com crianças do $4^{\circ}$ e $5^{\circ}$ ano do Ensino Fundamental, no Centro de Educação Unificada (CEU) Três Pontes (extremo leste da capital paulista), são apontadas como antecedentes do Slam Interescolar (AÇÃO EDUCATIVA, 2020).

A primeira edição aconteceu em 17 de novembro de 2015, com recursos dos próprios integrantes do coletivo. Dela participaram quatro escolas da zona leste de São Paulo, com poetas finalistas que se apresentaram no Teatro Flávio Império, também localizado naquela região da capital paulista (ASSUNÇÃO; JESUS, SANTOS, 2021, p. 19-20).

A partir desse momento, começa uma batalha travada entre indeferimentos em editais de financiamento público, realização de campanhas para arrecadação de recursos de custeio, cancelamento de reserva de teatro às vésperas de competições finais e perseguições político-ideológicas a professores/as de escolas envolvidas no projeto (ASSUNÇÃO; JESUS; SANTOS, 2021, p. 85; 136; 137).

Por outro lado, tal luta também foi acompanhada pelo aumento do número de escolas inscritas a cada ano:

Quadro 1. Número de escolas inscritas e de finalistas do Slam Interescolar (2015-2020).

\begin{tabular}{|c|c|c|}
\hline Ano & Número de escolas inscritas & Número de finalistas \\
\hline 2015 & 4 & 8 \\
\hline 2016 & 20 & 39 \\
\hline 2017 & 33 & 57 \\
\hline 2018 & 55 & 76 \\
\hline 2019 & 80 & 62 \\
\hline 2020 & 131 & 33 \\
\hline
\end{tabular}

Fonte: elaborado pelas autoras, com dados da coordenação do projeto Slam Interescolar SP2

2. Apresentamos mais um agradecimento especial a Uillian Chapéu pelo encaminhamento desses dados e pela partilha sempre solícita de informações sobre o Slam Interescolar. 
Os números refletem mudanças que foram ocorrendo ao longo da trajetória de seis anos do projeto. Entre 2015 e 2016, participavam das finais da competição até dois alunos de cada escola inscrita. A partir de 2017, passa a haver apenas um finalista por inscrição e, desde 2018, há chaves separadas para os ensinos fundamental e médio, sendo que algumas escolas participaram com representantes das duas etapas. A diferença entre inscritos e finalistas pode indicar desistências das escolas ao longo do processo ou impossibilidade de participação de estudantes nas finais. Em 2020, tal diferença foi mais significativa por conta da pandemia de Covid-19, como voltaremos a discutir mais adiante.

Ao destacar o aumento do número de inscrições recebidas a cada ano, Uillian Chapéu (AÇÃO EDUCATIVA, 2020) aponta que essa expansão representa uma progressão geométrica e geográfica: além da participação de estudantes de diferentes territórios da cidade de São Paulo, a partir de 2018, somaram-se jovens slammers de outras cidades do Estado, como Campinas e Hortolândia, graças à divulgação da professora Cynthia Agra de Brito Neves, da Universidade Estadual de Campinas (ASSUNÇÃO; JESUS, SANTOS, 2021, p. 88).

Em 2016, poetas da cena do slam paulistano passaram a contribuir com o projeto, por meio de visitas esporádicas a escolas participantes, nas quais poderiam oferecer oficinas de escrita, voz e corpo (AÇÃO EDUCATIVA, 2020). Essa experiência inicial de parceria com poetas-formadores, que já vinha sendo adotada no Rio de Janeiro pelo Slam Intercolegial da Festa Literária da Periferia (FLUP), foi inspirada na metodologia da Apples and Snakes, escola de Poesia Falada da Inglaterra (ASSUNÇÃO; JESUS; SANTOS, 2021, p. 200).

Em 2019, quando o Slam Interescolar foi finalmente contemplado no edital público da $3^{\text {a }}$ edição do Fomento à Cultura da Periferia do Município de São Paulo, foi possível oficializar a figura do poeta-formador. Passa a ser um mediador que, para além das oficinas, auxilia também na realização dos campeonatos escolares, as prévias do interescolar (ASSUNÇÃO; JESUS, SANTOS, 2021, p. 136).

Nesse contexto, desenha-se uma pedagogia do slam, que se inicia com a realização de um ciclo formativo com poetas-formadores e professores/as das escolas, para apresentar, sobretudo a estes/as importantes parceiros/as do projeto, a história do movimento, o funcionamento da competição, bem como oficinas de escrita, corpo, voz e performance (ASSUNÇÃO; JESUS, SANTOS, 2021, p. 197-198).

Tal percurso formativo é retroalimentado por meio de avaliações parciais e finais do Slam Interescolar, bem como pela interação contínua entre a coordenação do projeto, educadores/as e pesquisadores/as em grupo conectado em um aplicativo de mensagens, canal de comunicação e de troca de informações sobre slam e educação que se mantém ativo ao longo do ano, mesmo após as rodadas da competição.

Em 2020, intensificar esse diálogo a distância foi fundamental para animar a participação no evento, que ocorreu na modalidade online. Tal escolha se repetiu em 2021 em razão do distanciamento social necessário no contexto da pandemia de Covid-19. Para os/as estudantes, a falta de acesso à internet e a equipamentos adequados, ou seja, a exclusão digital entre as juventudes mais empobrecidas pode ter limitado, segundo Alcalde (AÇÃO EDUCATIVA, 2020), a participação efetiva das 131 escolas inscritas naquele ano: como notamos no quadro 1, apenas 62 se mantiveram ativas ao longo do processo.

Cristina Assunção aponta que, a despeito dessa situação, a adesão significativa ao projeto se deve ao envolvimento de professores/as não só de língua portuguesa, mas também de outros componentes curriculares (AÇÃO EDUCATIVA, 2020) que levam os slams para as escolas, sobretudo as públicas.

A esse respeito, é importante destacarmos que, em 2019, pela primeira vez, todos/as os/as inscritos/as eram matriculados/as em redes públicas de ensino municipais ou do próprio Estado de São Paulo (ASSUNÇÃO; JESUS, SANTOS, 2021, p. 251). Em consulta ao coletivo, confirmamos que esse perfil também se repetiu na edição online de 2020, ou seja, mesmo enfrentando todas as dificuldades de acesso à internet, inclusive para manterem-se em ensino remoto, as escolas públicas reafirmaram sua adesão ao Interescolar.

Para além do papel fundamental dos/as educadores/as dessas redes de ensino, é importante destacar a importância da atuação dos/as estudantes para o desenvolvimento do projeto, em diversas frentes: como poetas, slammasters (apresentadores do slam), produtores de cartazes, zines e plaquinhas de notas, por exemplo. Ainda segundo Cristina, é a oportunidade de "produzir literatura viva dentro da escola (...) e quebrar o muro que separa professor e aluno" (AÇÃO EDUCATIVA, 2020).

Aqui dialogamos brevemente com Neves (2021a) e apontamos essas atividades de interação, formação e de organização do slam nas comunidades escolares como constitutivas de práticas de letramentos literários, ou seja, 
como parte das "(...) práticas sociais e culturais que envolvem a leitura e a escrita poéticas e a performance (nas escolas)" (NEVES, 2021a, p. 82).

Também ousamos assinalar nossa intenção de apreciar tais letramentos sob lentes translíngues, especialmente por meio do que Ofélia García (2020) destaca acerca da potência da colaboração nas práticas pedagógicas enativoperformativas que envolvem artes (ADEN; ESCHENAUER, 2020). Tal concepção nos leva a ressaltar a atuação conjunta de corpo, linguagem, histórias e culturas (GARCÍA, 2020a, p. xix) naquelas experiências estéticas vivenciadas "das ruas para as escolas e das escolas para as ruas" (ASSUNÇÃO, JESUS, SANTOS, 2021).

Do slam realizado com educadores/as, poetas formadores/as, estudantes e membros do coletivo Slam da Guilhermina emergem sensibilidades de mundo (MIGNOLO, 2017), bem como repertórios e entendimentos outros, que se encontram muito além daqueles prescritos nos currículos homogeneizantes (as bases comuns curriculares) e por meio dos quais vislumbramos, com Catherine Walsh (2019), pedagogias decoloniais criadas nas gretas (ou nas fendas) do sistema de guerra-morte mundial:

A atual violência física, sexo-genérica, sociocultural, epistêmica e territorial desespera. Também desespera a busca de respostas às perguntas praxistas do que fazer e - mais criticamente - de como fazê-lo. Ou seja, como criar, fazer e caminhar hoje processos, projetos e práticas - pedagogias como metodologias imprescindíveis, diria Paulo Freire - a partir das gretas deste sistema de guerramorte mundial. (...) Talvez sejam as gretas existentes e as que vão tomando forma "no-lugar" (assim recordando a formulação e conceitualização de Arturo Escobar) que dão pauta, espaço, causa, posição, realização e razão às práticas pedagógicas descoloniais (WALSH, 2019, p. 96-97)

Longe dos "outros 500" da França (JESUS, 2021, p. 14) e localizados nos 500 do sul global (SANTOS, 2007), lugar onde as violências do sistema de guerra-morte mundial atingem especialmente os corpos das juventudes empobrecidas das "quebradas", os grupos que fazem o Slam Interescolar crescer a cada ano têm desenhado uma pedagogia entre as gretas da constante luta por recursos públicos para a execução de suas ações de formação, colaboração e encontro.

São agentes que rompem situações-limite e insistem no inédito viável freiriano (FREIRE [1992], 2018; LIBERALI, 2020), no "(...) porvir que ainda não foi experimentado como tal e, ao mesmo tempo, (...) não é negativamente utópico, mas afirmativamente possível, realizável, exequível" (KOHAN, 2019, p. 146). O slam nas escolas viabiliza e torna percebida-destacada a cada estudante do projeto a possibilidade do ser mais (FREIRE, [1992] 2018, p. 279), a vocação epistemológica e ontológica dos seres humanos (KOHAN, 2019, p. 67).

Talvez seja por isso que vemos nas gretas criadas pelo slam nas escolas a discussão sobre pautas permanentemente vigiadas por projetos políticos interessados no aniquilamento do pensamento crítico na educação brasileira, como é possível destacar em relatos da aqui já assinalada perseguição a educadores/as envolvidos/as no projeto:

\footnotetext{
Um pai fez uma denúncia por escrito e a protocolou na ouvidoria da Secretaria de Educação dizendo que o grupo que visitou a escola de seu filho praticou apologia ao racismo reverso (...). Uma mãe formalizou uma denúncia na Diretoria de Ensino dizendo que sua filha foi obrigada a participar de uma atividade que tinha gritos de guerra contra o governo. E que as poesias diziam que negros deveriam ser mais bem reconhecidos que os brancos, já que sofreram mais. E, então, a mãe questionou: Qual o problema da minha filha em ser branca? E concluiu: É uma pena que isso esteja ocorrendo na periferia. Resultado: algumas diretoras de escola cancelaram a participação no Interescolar e alguns professores responderam a processos administrativos (ASSUNÇÃO; JESUS; SANTOS, 2021, p. 137; 138).
}

Tais narrativas dão conta do incômodo causado pelas frestas que, desde 2015, têm tomado forma e caminhado pela via poética para romper com o silenciamento das vozes das juventudes até então fadadas "a ser menos" (FREIRE, [1992] 2018, p. 279) entre aquelas violências "gritadas" por Walsh (2019). Para converter o "ser menos" em "ser mais", é fundamental que se mantenha a marcha freiriana (para muitos, incômoda), das ruas para as escolas e das escolas para as ruas, afinal,

É preciso então sair do lugar, andar viajar, errar... como uma manifestação política de inconformismo perante o mundo que não nos deixa "ser mais", que nos impede de ser o que somos, que reage hostilmente contra outros modos e outras maneiras que não as consagradas, como forma de contestação e outro mundo possível (KOHAN, 2019, p. 139).

Desse modo, quando Cristina Assunção (AÇÃO EDUCATIVA, 2020) aponta os temas que em geral perpassam as produções dos/as slammers nas escolas (meninas contra o patriarcado, amor, homofobia, política, racismo, depressão e suicídio, por exemplo), compreendemos, sob uma ótica translíngue (GARCÍA, 2020a, p. xix), que não podemos isolar tais temáticas e tampouco as linguagens, a gramática do cotidiano (EVARISTO, 2019) por meio das quais as pautas são tratadas (ou gritadas). 
Como veremos adiante, o papel de transformação social e de transgressão de padrões normativistas de que se investe a perspectiva da translinguagem nos impele a não apreciarmos separadamente criatividade e criticidade naquelas práticas de letramentos literários. Assim, não se trata de avaliar apenas "o como" implicado na integração desses aspectos, mas também de perguntar-se por que certos corpos (negros, imigrantes, indígenas, pobres, feminizados, transgêneros) se recusam a atuarem sob a legitimidade de sujeitos de escuta monolíngues, cisnormativos e brancos (GARCÍA, 2020a, p. xix).

Tal atuação ocorre em espaços translíngues (ou nas gretas) abertos/as pela arte que, para além de nos emocionar, só pode ser transformadora se desafiar as desigualdades estruturais que não colocam aqueles corpos em lugares diferentes dos que hoje ocupam. Quando colaboram, escrevem e performatizam as temáticas que atravessam suas poesistências (NEVES, 2021b, p. 8), os/as estudantes estão gritando (ou translinguando) por entre gretas desde as quais anseiam o rompimento de bases curriculares homogeneizantes, de cânones literários normalizados (e normatizantes), de estruturas sociais modernas imbricadas na permanente colonialidade do poder, do saber e do ser (MALDONADO-TORRES, 2018, p. 28; 32).

Desse modo, quando educadores/as abraçam a proposta do slam, além de participarem de um movimento em que a partilha de saberes é um princípio fundador (KRAYNAK, SMITH, 2009), permitem que os/as jovens criem gretas nos muros sólidos de instituições como a escola, fazendo ouvir para além dela - nas ruas - a tradução de repertórios, entendimentos, mundos e corpos não normalizados e em devir, tal como a desejada transformação da sociedade que os lançou, até então, ao caos das desigualdades, da violência e da morte.

Tal leitura sobre a trajetória do Slam Interescolar se desenha, portanto, entre as gretas da Linguística Aplicada Indisciplinar (MOITA-LOPES, 2006), lugar desde o qual ousamos somar à perspectiva dos slams nas comunidades escolares como práticas de letramentos literários (NEVES, 2021a) a possibilidade de avaliá-los também sob o viés das práticas translíngues, sobre as quais discutiremos a seguir.

\section{TRANSLINGUAGEM E DECOLONIALIDADE: ENTENDIMENTOS E MOVIMENTOS PARA A TRANSFORMAÇÃO}

O termo translinguagem, nas últimas décadas, tem sido foco de crescente interesse de estudiosos vinculados aos mais diversos campos, tais como a linguística aplicada, a pedagogia, a comunicação multimodal e transmodal, artes visuais, música e estudos discursivos, somente para citar alguns (LI WEI, 2018).

Ao revistarmos Canagarajah (2013), podemos dizer que a virada trans envolve, pelo menos, dois pressupostos centrais, quais sejam: 1) a comunicação transcende a noção de línguas nomeadas; 2) a comunicação transcende o uso de palavras e, assim, envolve recursos semióticos diversos, bem como propiciamentos ecológicos variados.

$\mathrm{O}$ autor prossegue enfatizando que as pessoas consideradas monolíngues, na verdade, apresentam um repertório constituído por uma complexa gama de registros, variedades linguísticas e discursos, que revelam marcas de suas histórias de vida. Assim sendo, com base em Megale e Liberali (2020), nossos repertórios vivenciais mostramse marcadamente translíngues.

Pela ótica da translinguagem, portanto, "somos todos translíngues, e não falantes nativos de uma única dada língua" (CANAGARAJAH, 2013, p. 8). Por consequência, entendemos que, mesmo sendo considerados oficialmente falantes monolíngues, pelo peso de uma ideologia dominante redutora e opressiva, podemos nos entender como falantes bi/multi/plurilíngues, pela complexidade de nosso repertório, singular e multissemioticamente construído ao longo de nossas trajetórias.

Por sua vez, esse entendimento alinha-se ao pensamento do ć́rculo bakhtiniano ao aproximar-se da natureza heteroglóssica da linguagem. Como salientado por vários autores no campo da translinguagem, entre eles García e Li Wei (2014), Rocha e Maciel (2015), entre tantos outros, as práticas translíngues são sempre historicamente produzidas e, assim, acentuadas ideologicamente e marcadas pela multiplicidade de discursos, vozes e linguagens sociais. Conforme discorre Bakhtin (2015), essa tensa pluralidade de linguagens, vozes, visões de mundo, retratada originalmente pelo termo russo raznorétchie, revela-se produto da estratificação de uma dada língua, em uma multiplicidade de dialetos, jargões e falares sociais, situados em meio à tensão ideológica de forças centrípetas, que visam à estabilização de uma ordem social autoritária, e de forças centrífugas, que buscam a desestabilização.

Bezerra (2015, p. 247), por sua vez, opta pelo termo heterodiscurso para referir-se a essa "discrepância de palavras; de sentidos; diferença de opiniões; de avaliações; divergência", a fim de evidenciar que tal pluralidade 
discursiva, na filosofia bakhtiniana, refere-se a "um heterodiscurso social que traduz a estratificação interna da língua e abrange a diversidade de todas as vozes socioculturais em sua dimensão histórico-antropológica", fecundando as práticas sociais por meio da dissonância desestabilizadora.

Ao discutirem sobre a heteroglossia (ou, como preferimos aqui chamar, heterodiscurso), Blackledge, Creese e Takhi (2013) apoiam-se também no trabalho de Bailey (2012), para salientar a intrínseca relação entre esse conceito e as ideias de indexicalidade e de intertextualidade, conforme pensadas por Pierce (1955) e Silverstein (2003). Nesse horizonte, a palavra pode apontar para algo, pertencer a algum domínio ou ser reconhecida, de maneira particular, como representativa de "(...) um certo conjunto de valores, uma ideologia, um grupo social, uma nacionalidade, entre outros" (BLACKLEDGE, CREESE; TAKHI, 2013, p. 62).

Nesse sentido, os falantes irão sempre expressar suas vozes, ou seja, certas posições sociais, ao posicionaremse em relação a outras pessoas e ao mundo à sua volta, produzindo determinadas associações indexicais e avaliações. Apoiando-se em Heller (2011), esses autores prosseguem afirmando ser muito importante, para o enfrentamento da orientação monolíngue, que o foco de nossas análises não se restrinja à descrição de quais línguas nomeadas ou demais recursos semióticos estão presentes em determinadas práticas sociais, mas também se volte às razões pelas quais os sentidos estejam sendo criados de determinadas maneiras, em vez de outras, e pelos efeitos produzidos. Nesse viés, a orientação translíngue irá se ocupar da análise sobre como as práticas de linguagem estão "reproduzindo, negociando e contestando a diferença e a desigualdade social" (BLACKLEDGE, CREESE; TAKHI, 2013, p. 62), ao mesmo tempo em que se compromete com a reconstrução de possibilidades para a emergência de sensibilidades outras de mundo (MIGNOLO, 2017).

Assim sendo, concordamos com a definição de McKinney $(2017$, p. 2) que, embasando-se no pensamento de Heller (2007) e Blommaert e Rampton (2011), compreende a linguagem como "um conjunto de recursos social, cultural, política e historicamente situado" e, portanto, também como parte constitutiva de um repertório multissemiótico mobilizado nos processos, sempre corporificados e coordenados, de produção de sentidos. Ao discutirem a noção de repertório verbal, como inicialmente pensado por Gumperz (1964), Megale e Liberali (2020, p. 64) corroboram o pensamento de Busch (2012) e defendem que o conceito seja expandido para além de sua ligação a uma comunidade de fala, a fim de que este possa "assumir uma perspectiva biográfica que vincule o repertório linguístico do sujeito à sua trajetória de vida" e, assim, refletir toda sua tonalidade experiencial, sociocultural, ideológica e política.

Nesse horizonte, Pozza (2017) salienta que a translinguagem tem sido recorrentemente mobilizada em pesquisas sobre a educação de grupos minoritários ou minoritarizados, devido à sua forte ligação com a luta por justiça social e cognitiva. Mazzaferro (2018, s/p), por sua vez, também ressalta o caráter transformativo da translinguagem que, vivenciada como prática cotidiana, nos mais diversos campos da vida social, pode contribuir para promover o enfrentamento de ideologias opressoras, em suas mais diversas ordens, por meio da construção de um espaço de ação ética e esteticamente compromissado com a pluralidade e a equidade.

A esse respeito, Li Wei (2011) esclarece que a ideia de translanguaging é transformativa em seu cerne, uma vez que engloba o entrecruzamento entre diferentes estruturas e sistemas semióticos, incluindo-se, portanto, a multiplicidade de modos e modalidades nos processos de produção de sentidos, bem como o ato de atravessá-los, permitindo a emergência de um pensamento que extrapole esses contornos e desafie a ordem hegemônica imposta. Assim, a translinguagem ou a prática translíngue (CANAGARAJAH, 2013), aqui entendidas como noções intercambiáveis, pressupõe um movimento transgressivo, a partir do qual "a forma, a função e o sentido de signos linguísticos e semióticos são transformados e combinados, a fim de possibilitar a criação de novas subjetividades, identidades e ideologias" (MAZZAFERRO, 2018, s/p), em uma lógica alternativa, alinhada à decolonialidade (MIGNOLO, 2000, 2017; GARCÍA; LI WEI, 2014; GARCÍA; ALVÍS, 2019).

Apoiados em Menezes de Souza e colaboradores (2019), podemos compreender as chamadas teorias decoloniais, bem como as epistemologias do sul, como teorizações fortemente posicionadas contra a universalidade. Esse posicionamento mostra-se decolonial, à medida que pressupõe o enfrentamento do racismo, da discriminação cultural e dos demais modos de subalternização presentes em nossa sociedade. Para esses autores, o combate à lógica colonial, autoritária e perversa envolve o reconhecimento da complexidade constitutiva das relações sociais e da nossa existência, que refuta qualquer forma de reducionismo, bem como a conscientização acerca da cumplicidade.

Menezes de Souza et al. (2019, p. 10) chamam atenção para o fato de que“ [...] fazemos parte de um mesmo sistema social - não há um lado de fora dele. Se não pensarmos como cada um de nós contribuímos para o status quo, e se nos silenciamos diante dele, somos cúmplices". O mesmo argumento é defendido por García (2020a) ao ressaltar 
a natureza radicalmente intercultural da translinguagem. A interculturalidade, conforme aponta Zagada (2018), emergiu conceitualmente nas ciências sociais como uma possibilidade de enfrentamento da concepção monolíngue e vertical característica das relações sociais e práticas educacionais na América Latina. Com o propósito de desafiar o pensamento hegemônico e buscar formas estratégicas de luta em prol de mudanças estruturais e sistêmicas, a noção de interculturalidade crítica insere a prática intercultural em relações de poder, permitindo o entendimento da interculturalidade "como produto de um campo de forças" (ZEGADA C., 2018, p. 474).

Essa abordagem fortalece o potencial contestatório e desestabilizador de processos de descolonização e de dessubalternização, principalmente porque enfrenta o pensamento abissal (SANTOS, 2007), atravessa a diversidade e posiciona a diferença como força motriz para o reconhecimento das histórias, valores, conhecimentos, culturas e experiências de grupos marginalizados (ZEGADA C., 2018). Ao apoiar-se na ideia de inteligibilidade recíproca entre culturas e no conceito de tradução intercultural, conforme proposto por Santos (2010), Zegada C. (2018, p. 475) salienta a importância de abordarmos e vivenciarmos a interculturalidade criticamente, a fim de captarmos "os momentos do processo de desconstrução/reconstrução que transcende a relação entre culturas para o plano dos movimentos coletivos". Assim, rompendo com uma visão superficial de diversidade, a interculturalidade crítica, em sua radicalidade, "não existe sem o outro", pressupondo a existência de coletivos para a realização desobediente de "saberes, práticas e experiências", em um contexto de assimetrias produzidas historicamente.

Nesse horizonte, entendemos que práticas translíngues, radicalmente interculturais, situam o engajamento de grupos estigmatizados e excluídos em um cenário em que a positividade das marcas identitárias, culturais e linguísticas desses coletivos possam desafiar as linhas abissais e promover possibilidades de reconstrução de realidades alternativas, "sobre um horizonte de equivalências, de diálogos de saberes, de aprendizagens partilhadas [...]" (ZEGADA C., 2018, p. 475). Nesse contexto, para García e Li Wei (2014), em sua natureza transgressiva e insubordinada, a translinguagem remete à ideia de transculturação, conforme proposto pelo antropólogo Fernando Ortiz, uma vez que, rompendo com contornos e fronteiras nítidas, refere-se a um processo de produção de sentidos a partir do qual uma nova realidade emerge. Podemos dizer, então, que as práticas translíngues podem ser vistas como um novo fenômeno, radicalmente original, complexo, independente (GARCÍA; LI WEI, 2014). Nesse enfoque, a translinguagem:

(...) não se refere a duas línguas separadas nem à síntese de diferentes práticas de linguagem ou a uma mistura híbrida. Ao invés disso, a translinguagem refere-se a práticas novas de linguagem, as quais tornam visíveis a complexidade das trocas linguísticas entre pessoas com diferentes histórias, e as quais permitem emergir histórias e compreensões que haviam sido enterradas em meio a identidades linguísticas fixas, conformadas aos estados-nação [...]. (GARCÍA, LI WEI, 2014, p. 21, ênfase no original).

Para embasar sua visão acerca do conceito de translinguagem, García e Li Wei (2014) recorrem às ideias defendidas por Mignolo (2000) que, entre outras questões, discute a noção de languaging de modo alinhado ao pensamento fronteiriço, a fim de refutar uma abordagem redutora perante a língua /linguagem e desafiar seu papel como instrumento de controle do Estado.

A partir da visão dos referidos autores, a translinguagem cria um espaço social, crítico, criativo e potencialmente transformador para o falante bi/multilíngue. Podemos afirmar que a translinguagem "combina diferentes dimensões de sua história pessoal, experiência e contexto, de sua atitude, crença e ideologia, de sua capacidade cognitiva e física, permitindo uma atuação coordenada e significativa, transformando-a em uma experiência de vida" (LI WEI, 2011, p. 1223).

Nesse viés, a perspectiva translíngue, como salientam Makoni e Pennycook (2007), desafia o pensamento monolíngue ao reconhecer que as línguas, como sistemas linguísticos passíveis de reconhecimento (por exemplo, língua inglesa, portuguesa, chinesa etc), são objetos sociais e não meramente linguísticos. Portanto, as línguas ou idiomas nomeados podem ser vistos como construções ideológicas que historicamente remetem à emergência dos Estados nacionais, no século XIX, e que perpetuam relações de poder assimétricas em detrimento da pluralidade linguística e identitária de nossos dias.

A visão redutora de linguagem também é desestabilizada por Garcia e Li Wi (2014) que a compreendem como um verbo - languaging -, graças às ideias de Maturana e Varela (1998). García e Li Wei (2014, p. 10) acrescentam que o pensamento de Juffermans (2011) permite-nos entender a linguagem como "(...) um sistema sociolinguístico construído e habitado pelas pessoas". De acordo com Cowley (2019), em uma abordagem ecolinguística, o conceito de languaging desafia as noções de sistemas linguísticos e de uso da linguagem, uma vez que o foco na natureza 
corporificada e situada das práticas sociais contribui para salientar os modos pelos quais as pessoas coordenam recursos materiais e imateriais para produzir sentidos em detrimento de um olhar demasiadamente segmentado e voltado ao sistema. Para o autor, essa abordagem pode contribuir para o desenvolvimento de uma consciência que, orientada pelas ideias de justiça social e cognitiva, venha a favorecer maneiras coletivas de ação no mundo.

Esses processos translíngues de construção de sentidos, conforme aponta Pennycook (2017), revelam modos dinâmicos, situados, corporificados e distributivamente coordenados de existência na e pela linguagem. Com base nos trabalhos de Appadurai (2015), tais processos são vistos pelo referido autor como uma assemblagem, ou seja, como arranjos, complexamente constituídos e, portanto, indivisíveis, que abarcam uma gama muito diversa de elementos. A assemblagem apresenta-se, pois, como um todo de sentido, de natureza multissemiótica, multimodal e multissensorial, que ganha forma e estabilidade temporárias, em uma lógica não hierárquica, em meio a práticas translíngues. Parece importante ressaltar que, como enfatizam Blackledge e Creese (2017), o corpo é parte constitutiva desse repertório translíngue que, alinhado em quadros e espaço-temporais específicos, realizam os contornos dessa dinâmica assemblagem.

Nesse contexto, entendemos que, assim como a palavra ganha vida "na fronteira de meu contexto com o contexto do outro" (BAKHTIN, 2015, p. 57), em um processo de produção de sentidos translíngue, nosso repertório vivencial realiza-se, sempre de modo ideológica e afetivamente marcado, nas porosas fronteiras da multiplicidade de elementos que dão contorno temporário a essa dinâmica assemblagem (ROCHA; MEGALE, 2021). Nessa perspectiva, assumir a linguagem como verbo pressupõe a ideia de que enunciar, em um tempo-espaço específico e de um lugar único, realiza-se como "ato singular, participativo, não indiferente" (PONZIO, 2017, p. 21). O que dá unicidade ao mundo da teoria e ao mundo da vida, para Bakhtin (2017), é exatamente a experiência desses elementos, de modo único, irrepetível e sempre inacabado. O sujeito bakhtiniano nasce e vive das/nas fronteiras, respondendo ao mundo e a tudo o que o cerca, de modo único, sempre como um ser em devir. Nossa responsabilidade ética, por sua vez, encontra-se também "na vida-como-ato", porque é exatamente "ao agir", que me "torno responsável" (SOBRAL, 2019, p. 44).

Existir, na e pela linguagem, em toda sua complexidade e amplitude, revela-se, assim, um existir como evento ou como acontecimento (BAKHTIN, 2017), que dá unicidade à vida, em seus diversos campos. Sobral (2019, p. 48) salienta que, seguindo postulados bakhtinianos acerca da vida singularizada no/pelo ato, "(...) o estético é também um dos componentes dessa vida e, como parte não pode ser maior do que o todo". Segundo esse autor, o elemento estético não pode, tampouco, alcançar, por si só, "(...) a unidade histórica do ser evento" (SOBRAL, 2019, p. 21). Nesse horizonte, nas fronteiras da vida e da arte, nossa realização como ser-evento pressupõe o agir dialógico e, assim, a presença do outro (SAMPAIO, 2019). Conforme salienta Sobral (2019, p. 48), a "empatia estética" demanda a exotopia, ou seja, a visão extraposta "da participação de cada sujeito no ser-evento", no acontecimento do existir.

Ao abordarmos o slam, nesse horizonte e perspectiva, percebemos que o movimento estético se realiza nas fronteiras e que, em sua singular unicidade, os participantes enunciam ao se engajarem em práticas poéticas translíngues, vivenciando a assemblagem como acontecimento do existir, este repertoriado e tonalizado de forma única e eticamente responsável. O slam, como uma prática translíngue e poético-literária, realiza-se, portanto, "(...) do lugar único de minha participação do existir, o tempo e o espaço são individuados e incorporados como momentos de uma unicidade concreta e valorada" (BAKHTIN, 2017, p. 121). Com base na arquitetônica potente desses letramentos literários como experiência do existir-como-evento, que implode limites rigidamente impostos, em favor da existência na porosidade das fronteiras (imaginadas e imagináveis), percebemos ecos bakhtinianos acerca de um sujeito concreto e único que, constituído pelo agir dialógico, responsível e responsável, abre possibilidades para a transformação, de si próprio e do mundo, por meio de seu ato. Nas palavras de Ponzio (2019, p. 21),

Inevitavelmente é no mundo vivido como singularidade, no mundo da vivência única, que cada um se encontra quando conhece, pensa, atua e decide; é daqui que participa do mundo em que a vida é transformada em objeto e situa a identidade sexual, étnica, nacional, profissional, de status social, em um setor determinado do trabalho, da cultura, da geografia política etc (PONZIO, 2019, p. 21).

Situado no campo escolar, o slam, nessa perspectiva, implode limites hegemonicamente impostos entre a vida vivida e o mundo da teoria. Os letramentos literários, nessa ótica, integram o repertório do sujeito-estudante, de forma situada e singularizada. O caráter libertário e decolonial dessas práticas, translíngues por natureza, ressignificam também a ideia de educação (linguística), permitindo que esta seja vivenciada a partir de um cronotopo educacional 
marcado por uma agência coletiva e por uma ética comunal, interessada na transformação de realidades (ROCHA; MEGALE, 2021).

A experiência educativa não se separa da experiência de vida, como bem postula Freire ([1992] 2018) e Kohan (2019), possibilitando que gritos ecoem a heterogeneidade de vozes e as dores existenciais de grupos subalternizados. Ao mesmo tempo, esse espaço translíngue e poético torna-se (educativamente) potente, porque abre espaço para o inédito viável (FREIRE, [1992] 2018; LIBERALI, 2020) e, assim, para a reexistência (SOUZA, 2011), ao ser repertoriado com movimentos de desestabilização da ordem social opressora, bem como de semeaduras mais socialmente e cognitivamente justas. Essa educação da vida e para a vida reflete a proposta de Sampaio (2019), por refletir a ideia de (trans)linguagem como experiência pensante no contexto educacional. Experiência pensante, porque demanda participação e responsabilidade ética.

Como ainda salienta Sampaio (2019, p. 312-313), "as palavras ganham vida "ao adentrarem a corrente verbal (multissemiótica e multissensorial, acrescentamos) do acontecimento vivo, atravessadas por valores e impulsionadas pelos contextos verbais e extraverbais do acontecimento histórico que o poeta (ou slammer, salientamos), autorcriador, acolhe, valora e redimensiona esteticamente". Experiência porque se realiza como ato e porque é volitiva e afetivamente marcada e sempre potencialmente transformativa. É um grito amoroso de guerra, pois é fortemente desobediente, com vistas a minar o sistema, e potentemente afetivo, para cativar e inspirar. Assim, essa experiência com a linguagem (SAMPAIO, 2019) é também educativa no sentido de mostrar-se um convite à escuta, radical e corporificada (KEATING, 2007), que nos ajuda a todos a "aprender a pensar a verdade do ser, como um acontecimento", em toda sua riqueza, contradição, inacabamento e complexidade (SAMPAIO, 2019, p. 317).

\section{GÉ PUTÁRE TENETEHÁRA: UM SLAM PARA SENTIPENSAR DESDE OS TERRITÓRIOS DA ESCOLA, DAS RUAS E DAS TELAS}

Tendo situado nosso referencial teórico nas fronteiras dos estudos sobre translinguagem e decolonialidade, passamos a avaliar o potencial transformador dos slams nas escolas, por meio de aproximações desses letramentos literários às práticas translíngues enativo-performativas, que se desenham a partir do quadro de referência desta abordagem apresentado por Aden e Eschenauer (2020, p. 5-6). Estas autoras, engajadas em pesquisas do campo da educação linguística e das artes (do teatro, mais precisamente), inspiraram-se nas dimensões de performatividade, propostas por Fischer-Lichte (2004), e no conceito central de emergência, oriundo do paradigma de enação, de Francisco Varela (1999).

Com o intuito de promovermos esse encontro a partir do contexto das escolas paulistas, avaliamos diferentes apresentações do Slam Interescolar SP 2020 (edição online), todas potentes para deslindarmos a análise a ser aqui realizada, mas que aqui delimitamos à produção da estudante de Ensino Médio Franciele Evangelista Apolinário. Graças ao já mencionado apoio do coletivo Slam da Guilhermina, foi possível estreitar a distância entre a poeta e sua professora de Indaiatuba-SP, para destacarmos, neste artigo, excertos do poema Gé putáre tenetehára, apresentado pela jovem via plataforma de streaming, em novembro de 2020 (SLAM DA GUILHERMINA, 2020) . $^{3}$.

Ao longo da análise, que compreende a avaliação de quatro eixos - emergência, experiência, corporeidade e transformação -, destacamos como a estética estimula a empatia entre a slammer e a audiência (da escola, das ruas e, na edição de 2020, também do ciberespaço), por meio de experiências sensório-motoras, de emoções e da metacognição. Tal movimento empático revela-se, por sua vez, como a força motriz da flexibilidade propiciada pela translinguagem. Resulta desse movimento uma matriz relacional em que atuam o eu (self), o outro e o contexto (ADEN; ESCHENAUER, 2020, p. 7).

Ao aproximarmos tal matriz ao contexto dos slams realizados entre as escolas e as ruas do Sul Global, a primeira dimensão da abordagem enativo-performativa a ser avaliada é a da emergência, que se refere à possibilidade de acessarmos diferentes formas de conhecimento por meio do acoplamento estrutural percepção-ação. Nesse caso, a percepção não é passiva: ela emerge da interação entre experiências e significados partilhados em novas realidades (ADEN; ESCHENAUER, 2020, p. 5).

Quando Franciele dá início à experiência estética de apresentar o seu slam, vislumbramos sentidos que deslizam do corpo-discurso (NASCIMENTO, 2018) de uma adolescente, por meio da voz de um lírico em primeira pessoa.

3. A apresentação de Franciele pode ser apreciada entre os minutos 49:24 e 52:40 do vídeo que está disponível em: https://www.youtube.com/ watch?v=LdTTnbFvdqw Acesso em: 19 out. 2021. 
Ainda que não consigamos reproduzir nesta página todo o engajamento da slammer em provocar nossa empatia para com o assunto abordado, seus movimentos nos convidam a acessar, desde o espaço limitado de uma tela, a situação inicial da história da invasão das terras de povos originários pelos homens brancos portugueses, os caraíbas:

Consigo sentir o balançar das águas

Fecho os meus olhos e sinto o sol beijando meu rosto

Sentada na areia, sorrindo como criança

Vendo o horizonte que já não se faz reto como suposto

Sombras grandes navegam em ordenança

E o grito vem

CARAÍBA

A assemblagem constituída por imagens, sensações e sons marcados por meio de figuras de linguagem, no texto poético falado, e de gestos, no enquadramento da tela, é parte dos repertórios vivenciais, marcadamente translíngues, acionados pela estudante. Eles trazem à tona sua percepção-ação sobre uma temática que atravessa os currículos escolares, porém quase sempre de forma a reiterar a desumanização dos corpos que aqui foram encontrados.

Os entendimentos de Franciele sobre aquela história contada desde a perspectiva dos colonizadores se confirma em depoimento encaminhado via aplicativo de mensagens, quando the perguntamos por que escolhera abordar tal temática no seu slam:

Eu escolhi escrever sobre indígenas porque é um tema a ser debatido, principalmente agora nesse cenário de pandemia. Esses povos são nossas origens, são o nosso começo. Vê-los sendo destruídos, tanto por um vírus, como pela sociedade, a cada dia mais, é algo que me incomoda muito. É como se quem eu sou estivesse sendo arrancado de mim. Eu não conheço nenhum indígena, nunca tive contato com esse povo (a não ser pelo fato de meu avô ser descente de indígenas), mas quero poder lutar por eles, lutar junto a eles, quero poder fazer as pessoas entenderem que perder essas origens é como perder a identidade do Brasil, uma das únicas que nos restam diante de um país completamente influenciado por culturas exteriores ${ }^{5}$.

Da vivência situada no presente do caos pandêmico e no passado de sua ancestralidade, a jovem faz emergir, por meio de sua batalha poética, realidades sobre os povos originários ainda pouco imaginadas por uma audiência enredada em narrativas hegemônicas acerca do período das grandes navegações e das "descobertas", estas apresentadas, em geral, como o acontecimento definidor da noção do ser civilizado, o marco temporal do antropoceno (MALDONADO-TORRES, 2018, p. 30-31).

Ao acionar repertórios poético-literários, multimodais e multissensoriais para questionar as relações de poder que perpetuaram entre conteúdos possivelmente discutidos ao longo de sua vida escolar, Franciele mobiliza, na relação com seu público, elementos constitutivos da interculturalidade crítica (ZEGADA C. 2018) e, assim, capazes de desestabilizar aquele modo hegemônico de contar a História. Ao mesmo tempo, apresenta em seu slam a existência de epistemologias não situadas no eixo norte-ocidental (GARCÍÁ ALVIS, 2019, p. 26), narradas por corpos atravessados pela "violência física, sexo-genérica, sociocultural, epistêmica e territorial" do sistema guerra-morte de que nos fala Catherine Walsh (2019). Nas escolhas da slammer, vislumbramos, portanto, uma atitude translíngue e decolonial, por meio da qual escancara a indissociabilidade entre aqueles corpos e seus territórios (KRENAK, 2020).

A compreensão de que a Terra é um único organismo do qual fazemos parte se mantém, na verdade, entre aqueles que são considerados a sub-humanidade, os corpos esquecidos pelas bordas do planeta, os/as caiçaras, indígenas, quilombolas e aborígenes do Sul Global (África, Ásia e América Latina):

Existe, então, uma humanidade que integra um clube seleto que não aceita novos sócios. E uma camada mais rústica e orgânica, uma sub-humanidade, que fica agarrada na Terra. Eu não me sinto parte dessa humanidade. Eu me sinto excluído dela. Fomos, durante muito tempo, embalados com a história de que somos a humanidade e nos alienamos desse organismo de que somos parte, a Terra, passando a pensar que ele é uma coisa e nós, outra: a Terra e a humanidade. Eu não percebo que exista algo que não seja natureza. Tudo é natureza. O cosmos é natureza. Tudo em que eu consigo pensar é natureza. (KRENAK, 2020, p. 45)

Nesse sentido, as escolhas da poeta descortinam uma forma outra de sentipensar (WALSH, 2019) ou co-razonar (ESCOBAR, 2014, p. 16) seus entendimentos e vivências sobre os territórios, as culturas e os conhecimentos ancestrais de seu avô. Trata-se de traduções empáticas de mundo que ultrapassam os limites do lugar metafórico já conhecido em "sinto o sol beijando meu rosto" ou "sorrindo como criança". É exatamente com a assemblagem dessas imagens e multissensorialidades que escancara como ainda nos escapa, após tantos anos de resistência daqueles povos,

4. Tradução livre do tupi-guarani proposta pela slammer: "Como os indígenas nomeavam os europeus".

5. Depoimento de Franciele Evangelista Apolinário que nos foi encaminhado via aplicativo de mensagens em 17/06/2021. 
a possibilidade de que a natureza foi uma criação colonial para nos apartar das porções do organismo Terra, o corpoterritório a ser dominado, explorado e dizimado na ordem do sistema-mundo criado no paradigma da modernidade/ colonialidade (MALDONADO, 2019, p. 32).

Fazendo avançar essa leitura do eixo da emergência ao da realidade experiencial, seguimos Aden e Eschenauer (2020, p. 5) quando retomam a referência de Maturana e Varela (1998) ao contínuo devir das linguagens de que somos coletivamente constituídos. Nesse sentido, podemos levar adiante as vozes dos que nos antecederam por meio de experiências outras de agência no mundo, sendo, sob nosso ponto de vista, o slam uma delas.

Em uma sequência que compreende o deslocamento da cabeça e do olhar, bem como o gesto do dedo indicador apontado para seus/suas interlocutores/as, Franciele traz à tona tal devir ancestral, por meio da referência ao tremor do solo e da visita de gritos dos povos originários em sua poesia, para nos fazer experienciar o conflito do encontro entre aqueles corpos e os dos invasores de suas terras:

Os grãos de areias se agitam, sem mais ninguém

Sinto o chão tremer

Nepapáá, lá vem os caraibas

O homem branco pisa

Trazendo consigo as destruições

E o apocalipse concretiza

A chegada das pragas com as grandes navegações

A guerra passou aos olhos da kunbã muku' im

Ao longo da apresentação, o trânsito desses gritos indígenas evidencia outro repertório acionado no slam que não é valorizado na tradição cultural ocidental: a força da oralidade. Conforme aponta Paul Zumthor ([1990], 2018), nas línguas não escritas, a vocalidade da palavra constitui sua própria definição. Assim, somos afetados pelo contínuo de um protesto translíngue que emerge do Sul Global (SEVERO; ABDELHAY; MAKONI, 2020, p. 106), por meio do uso de recursos multimodais, multissemióticos e multissensoriais.

Desse modo, a mobilização das vozes dos povos originários não é encarada por nós como realizada por meio somente das marcas de mais um idioma nomeado utilizado na composição do poema, o que limitaria a potência de seus sentidos a uma perspectiva monoglóssica e hegemônica, perpetuando a visão idealizada de autonomia e separação entre línguas (GARCÍA; LI WEI, 2014; GARCÍA, 2020a/b). Ao enfatizarmos o potencial heterodiscursivo (BAKHTIN, 2015) dos slams, bem como nosso posicionamento entre as fronteiras da translinguagem e da decolonialidade, buscamos romper com tais visões redutoras e consideramos aquelas vocalizações como um dentre tantos outros recursos multissemióticos (CANAGARAJAH, 2013) acionados por Franciele em sua experiência estética.

Partindo desses princípios, dialogamos justamente com mais uma dimensão das práticas enativo-performativas: a corporeidade. Nesse eixo, o conhecimento se apresenta como algo que incorporamos e encarnamos, por meio de sensações, emoções e movimentos que servem de base a um pensamento abstrato.

Na apresentação de Franciele, os saberes até então silenciados sobre o que significou para os povos originários a chegada dos invasores portugueses não são compartilhados por meio de argumentos do racionalismo eurocêntrico. O estranhamento causado pela chegada daquela "gente estranha" foi incorporado pela expressão facial ${ }^{8}$ que constitui as emoções experimentadas naquele momento:

Para eles trouxe grandes conquistas

E descobertas como falam

Mas vos digo Abaitế, gente estranha

Que apunhalam

6. Tradução livre do urubu (família linguística do tupi-guarani) proposta pela slammer: "Papai".

7. Tradução livre do tupi antigo proposta pela slammer: "mocinha".

8. Cientes de que a captura de telas traz para a página imagens estáticas e, portanto, não representativas da sinestesia que emana do repertório poético-literário mobilizado por Franciele, decidimos mostrar frames da apresentação de seu slam como uma tentativa de possibilitar a expansão de sentidos, ao menos durante a discussão sobre o eixo da corporeidade proposto por Aden e Eschenauer (2020).

9. Tradução livre do tupi-guarani proposta pela slammer: "gente ruim, gente estranha". 


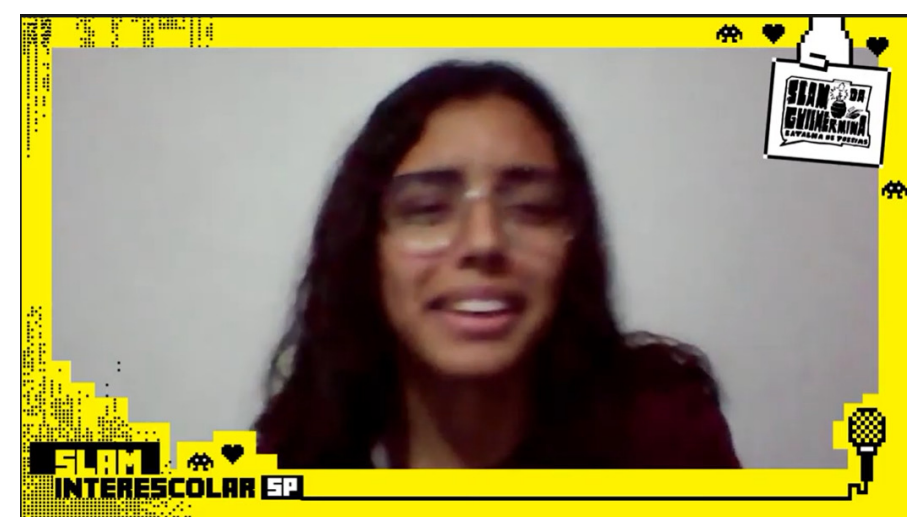

Imagem 1. Frame do verso "Mas vos digo Abaté, gente estranha Fonte: Slam da Guilhermina (2020)

Nessa corporeidade, também será experimentada a racialização, a Outridade determinada pelos brancos como antagonista de seu "eu" (self), da própria perversidade que negam e projetam em forma de violência racial sobre o/a colonizado/a, para legitimar, conforme nos aponta Grada Kilomba ([2008] 2019, p. 35-36), estruturas violentas de exclusão social.

Desse modo, à/ao Outra/o da pele escura é associado o que a sociedade branca reprime - a agressividade e a sexualidade. Isso faz aqueles corpos coincidirem com a "(..) a ameaça, o perigo, o violento e também o sujo, mas desejável, permitindo à branquitude olhar para si como moralmente ideal, decente, civilizada e majestosamente generosa" (KILOMBA, [2008] 2019, p. 37).

Franciele encarna criticamente essa Outridade e recupera a memória do que o cientificismo positivista chamou miscigenação, para recordar que estava em jogo o apagamento da pele escura, também gritada por sua linguagem ancestral em contínuo devir:

\footnotetext{
Chegaram sem avisar

E dominaram sem nem perguntar

O começo da mistura

Dizem miscigenação e pigmentos

Mas eu digo eçaraia ${ }^{10}$, escura

Eçaraia, O ESQUECIMENTO
}

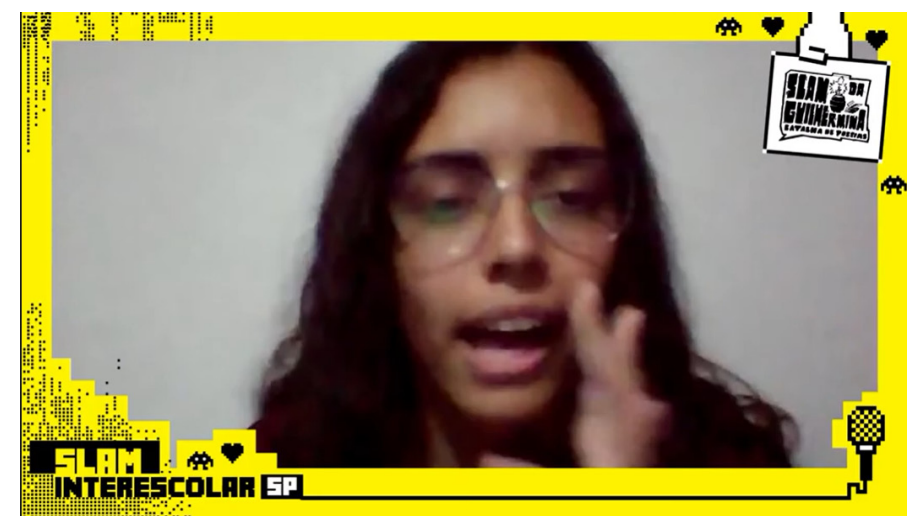

Imagem 2. Frame do verso Eçaraia, O ESQUECIMENTO

Fonte: Slam da Guilhermina (2020)

O esquecimento - eçaraia - não é permitido ao corpo que, após a invasão, não pode mais fechar os olhos para contemplar outros mundos (HAN, 2021). Ao abri-los, defronta-se com o caos do presente, a colonialidade permanente que o sub-humanizou: 
Nhunquére- ém ${ }^{11}$

Não quero dormir

NHUNQUÉRE-ÉM

Não quero fechar meus olhos

Para voltar àquele momento

Mas também não quero abri-los para esse novo mundo

Onde meu país me esqueceu, só lamento

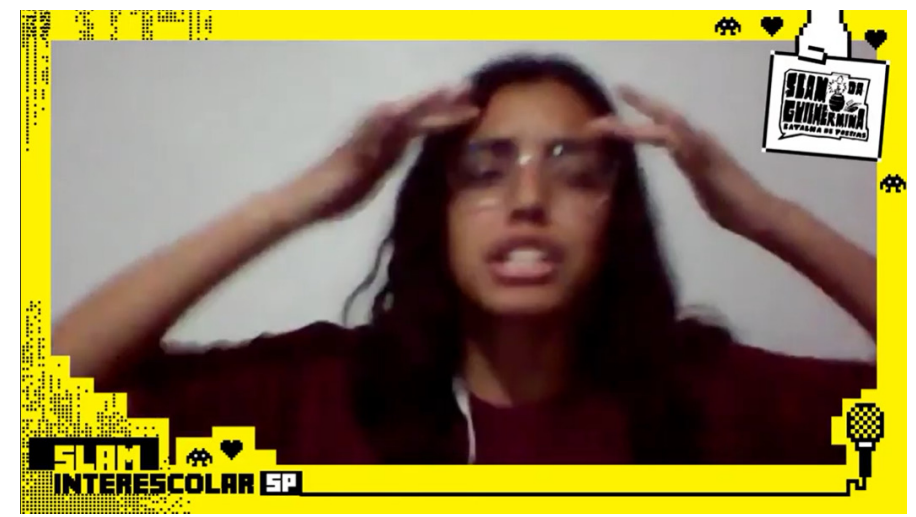

Imagem 3. "Não quero fechar meus olhos"

Fonte: Slam da Guilhermina (2020)

A menção ao ato de fechar e abrir os olhos é acompanhada da expressão facial aflitiva que se opõe ao corpo descrito na situação inicial do poema. Não perdura, entretanto, o estado de desespero, tampouco impera a prostração. Do caos é que emerge o grito de transformação por meio do qual seu poema se encaminha para o desfecho. Surge et ambula - levanta e anda - aparece como referência ao poema homônimo do moçambicano Rui Noronha (2008), lá um chamado para que a África marchasse rumo ao progresso produtor de barbáries (SOARES, ALVES, 2015); aqui, ao contrário, para reafirmar a necessidade de ruptura do antropoceno, a partir do Sul Global.

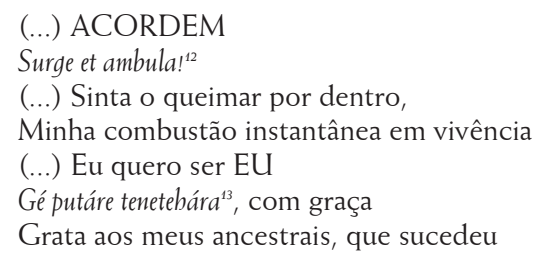

Adentrando já o eixo da transformação (ADEN; ESCHENAUER, 2020), a apresentação como um todo desvela sua potência para romper perspectivas que nos limitam ao familiar, abrindo espaço ao desconhecido e à construção de uma nova realidade. É nesse momento que vemos emergir a reafirmação do eu lírico sobre sua ancestralidade e sua necessidade de ser indígena, sem ser imolado/a na taça do sistema guerra-morte (WALSH, 2017; 2019) vigente desde a invasão de seu corpo-território.

Quero poder ser indígena,

Sem ter meu sangue em sua taça!

Emergem nessa experiência estética as vivências da estudante no Slam Interescolar, projeto cuja missão não se coaduna à noção de competição cooptada pela ótica neoliberal, mas como espaço social potencialmente crítico, criativo e transformador (LI WEI, 2011). É o que depreendemos de seu depoimento acerca do assunto:

A competição no slam interescolar não é apenas uma competição, é um lugar no qual você aprender realmente como a vida é, aprende o seu lugar dentro da sociedade e luta por reconhecimento, mas também não é apenas isso, é um lugar onde você se diverte e mantém uma cultura linda de poder escrever, ler, aprender e desenvolver poesias que podem mudar pessoas ${ }^{14}$.

11. Tradução livre do urubu (família linguística do tupi-guarani) proposta pela slammer: "não quero dormir".

12. Tradução livre do latim proposta pela slammer: "ergue-te e anda".

13. Tradução livre do guajajara proposta pela slammer: "eu quero ser índio".

14. Depoimento de Franciele Evangelista Apolinário que nos foi encaminhado via aplicativo de mensagens em 17/06/2021. 
O exemplo de Franciele nos permite reiterar, portanto, que as batalhas poéticas do projeto Slam Interescolar ampliam, sob a perspectiva dos letramentos literários e dos eixos das práticas translíngues enativo-performativo aqui mobilizadas, entendimentos não hegemônicos e novas realidades nas fronteiras das escolas paulistas e das ruas do Sul Global.

\section{CONSIDERAÇÕES FINAIS}

Neste artigo, buscamos lançar um olhar translíngue para o Slam Interescolar, orientando-nos pela proposta de compreensão enativo-performativa de práticas de linguagem na escola. Essa nos pareceu uma abordagem muito interessante, pois, ao mesmo tempo em que enfrenta visões redutoras de língua e de linguagem, em favor de um entendimento mais complexo e ecologicamente organizado, permite a compreensão de práticas linguísticas e de letramentos, em sua natureza situada e ideologicamente marcada, a partir de rupturas com a matriz colonial do poder. É o que procuramos ilustrar com a análise de Géputáre tenetebára, de Franciele Evangelista Apolinário, uma dentre tantas produções potentes para a transformação de realidades (e de gretas) entre o chão das escolas e o asfalto das ruas.

Assim sendo, reconhecemos o Slam Interescolar como prática poético-literária translíngue e, portanto, como complexos multissemióticos e multissensoriais realizados em quadros espaço-temporais particulares que, nas e para além das fronteiras entre línguas nomeadas, linguagens, vozes, discursos e territórios permitem emergir gritos de resistência, acompanhados por possibilidades de brechas no sistema e por suas semeaduras com sensibilidades outras de mundo. Nesse horizonte, a perspectiva translíngue, ao desafiar as mais diversas formas de subalternização, bem como de modos opressores de produção de sentidos e construção de saberes, permite situar o engajamento de grupos estigmatizados e excluídos em um cenário em que a positividade das marcas identitárias, culturais e linguísticas desses coletivos possam desafiar as linhas abissais, para, então, promover alianças que reflitam diálogos de saberes e de aprendizagem compartilhadas de forma horizontalizada.

Ao pensarmos o slam como acontecimento, em uma vertente translíngue enativo-performativa, sua realização se faz nas tensões fronteiriças, sendo tonalizada ideológica e afetivamente e abrindo-se heterodiscursivamente sempre para o devir. A força empática, que grita por justiça social e cognitiva e que dá o acabamento estético a essa prática, realiza-se no encontro dialógico, oportunizando o inédito viável, ou seja, abrindo possibilidades para a construção coletiva e comunal de outras realidades sociais e, assim, também linguísticas e educacionais. Na potência de sua energia translíngue e decolonial, o Slam Interescolar reflete um movimento de educação na vida e para a vida que, mobilizando repertórios vivenciais e de poesistência, inspiram o sentipensar e fortalecem a luta pela pluralidade de (re) existências.

\section{REFERÊNCIAS}

AÇÃO EDUCATIVA (2020). Slam e educação. Encontro Estética das Periferias. (58 minutos). Disponível em: <https:/www. youtube.com/watch?v=OY8i-vkyRQs> Acesso em: 16 abr 2021.

ADEN, J.; ESCHENAUER, S. (2020). Translanguaging: An Enactive-Performative Approach to Language Education. In: MOORE, E.; BRADLEY, J.; SIMPSON, J. (ed.). Translanguaging as Transformation: The Collaborative Construction of New Linguistic Realities. Bristol; Blue Ridge Summit: Multilingual Matters. p. 102-117. DOI: https://doi.org/10.21832/9781788928052-011

APPADURAI, A. (2015). Mediants, materiality, normativity, Public Culture, v. 27, n. 2, p. 221-237.

ASSUNÇÃO, C. A.; JESUS, E. A.; SANTOS, U. (2021). Das ruas para as escolas, das escolas para as ruas: Slam Interescolar. São Paulo: LiteraRua.

BAKHTIN, M. (1975). Teoria do romance I. A estilística / Mikhail Bakhtin. Tradução, prefácio, notas e glossário de Paulo Bezerra. Organização da edição russa de Serguei Botcharov e Vadim Kójinov. São Paulo: Editora 34, 2015.

BAKHTIN, M. (1979). Estética da criação verbal. Trad. Paulo Bezerra. São Paulo: WMF/Martins Fontes, 2010.

BAKHTIN, M. M. (2009). Para uma filosofia do ato responsável. São Carlos: Pedro e João, 2017. 
BAILEY, B. (2012). Heteroglossia. In: MARTIN JONES, M.; BLACKLEDGE, A.; CREESE, A. (eds.). The Routledge Book of Multilingualism. London: Routledge. p. 499-507.

BEZERRA, P. (2015). Breve glossário de alguns conceitos-chave. In: BAKHTIN, Mikhail. Teoria do romance I. A estilística / Mikhail Bakhtin. Tradução, prefácio, notas e glossário de Paulo Bezerra. Organização da edição russa de Serguei Botcharov e Vadim Kójinov. São Paulo: Editora 34. p. 243-249.

BLACKLEDGE, A.; CREESE, A. (2017). Translanguaging and the body, International Journal of Multilingualism, v. 14, n. 3, p. $250-268$. https://doi.org/10.1080/14790718.2017.1315809

BLOMMAERT, J.; RAMPTON, B. (2011). Language and superdiversity. Diversities, v.13, n.2. Disponível em: < http://www. unesco.org/shs/diversities/vol13/issue2/art1 >. Acesso em: 17 jul 2018.

BUSCH, B. (2012). The Linguistic Repertoire Revisited. Applied Linguistics, v. 33, n. 5, p. 503-523. Disponível em: https://www. heteroglossia.net/fileadmin/user_upload/publication/2012-Busch-Applied_Ling.pdf. Acesso em 15 jun. 2021.

CANAGARAJAH, S. (2017). Translingual practices and neoliberal policies: attitudes and strategies of African skilled migrants in Anglophone workplaces. New York: Springer.

CANAGARAJAH, S. (2013). Translingual Practice: Global Englishes and Cosmopolitan Relations. London/New York: Routledge.

CANAGARAJAH, S.; DOVCHIN, S. (2019). The everyday politics of translingualism as resistance practice. International Journal of Multilingualism, p. 1-18. Disponível em: < https://doi.org/10.1080/14790718.2019.1575833>. Acesso em: 10 nov. 2019.

CELANI, M.A.A. (1992). Afinal o que é Linguística Aplicada? In: Paschoal, M.S.Z., Cela- ni, M.A.A. (orgs.), Linguística Aplicada: da aplicação da linguística à linguística transdisciplinar. São Paulo: EDUC.

ESCOBAR, A. (2014). Sentipensar con la tierra: nuevas lecturas sobre desarrollo, territorio y diferencia. Medellín: Universidad Autónoma Latinoamericana UNAULA.

EVARISTO, C. (2019). Prefácio. In: Querem nos calar: poemas para serem lidos em voz alta. [recurso eletrônico]. São Paulo: Planeta do Brasil.

FABRÍCIO, B.F. (2006). Linguística Aplicada como espaço de desaprendizagem: redes- crições em curso. In: Moita Lopes, L.P. (org.), Por uma Linguística Aplicada INdisciplinar. São Paulo: Parábola..

FISCHER-LICHTE, E. (2004). Ästhetik des Performativen. Frankfurt-am-Main: Fischer-Verlag.

FREIRE, P. (1992). Pedagogia da esperança: um reencontro com a pedagogia do oprimido. 21. ed. Rio de Janeiro; São Paulo: Paz e Terra, 2018.

FREIRE, M. (2020). Linguistica Aplicada, complexidade e transdisciplinaridade: tecendo redes de sentido e articulando saberes, Educação \& Linguagem, v. 23, n. 1, p. 245-261. GARCÍA, O. (2009). Bilingual education in the 21st century: A global perspective. Oxford: Wiley-Blackwell.

GARCÍA, O. (2020a). Foreword: co-labor and re-performances. In: MOORE, Emilee; BRADLEY, Jessica; SIMPSON, James (Eds.). Translanguaging as transformation: the collaborative construction of new linguistic realities. Bristol: Multilingual Matteres, p. Xvii-xxii.

GARCÍA, O. (2020b). The education of Latinxs bilingual children in times of isolation: unlearning and relearning, Minne TESOL Journal, v., n.1, s/p.

GARCÍA, O.; ALVIS, J. (2019). The Decoloniality of Language and Translanguaging: Latinx knowledge-production. In: Journal of Postcolonial Linguistics, v. 1, 26-40. Disponível em: < https://iacpl.net/journal-of-postcolonial-linguistics-12019/thedecoloniality-of-language-and-translanguaging-latinx-knowledge-production/> Acesso em: 15 out. 2020.

GARCÍ A, O.; LI WEI. (2014). Translanguaging: language, bilingualism, and education. London: Palgrave Macmillan. 
GUMPERZ, J. J. (1964). Linguistic and social inter-action in two communities, American Antbropologist, v. 66, n. 6/2, p. 137-53.

HAN, B-C. (2021). Favor fechar os olhos: em busca de outro tempo. Petrópolis-RJ: Vozes.

HELLER, M. (2007). Bilingualism: a social approach. Basingstoke: Palgrave.

HELLER, M. (2011). Paths to post-nationalism. A critical ethnography of Language and identity. New York: Osford University Press.

JESUS, E. A. De Belleville ao Romano: o Slam da Guilhermina vai às escolas. In: Das ruas para as escolas, das escolas para as ruas: Slam Interescolar. São Paulo: LiteraRua, p. 14-17.

JUFFERMANS, K. (2011). The old man and the letter: repertoires of literacy and languaging in a modern multiethnic gambian village, Compare, v. 42, n. 2, p. 165-179.

KEATING, A. (2007). Teaching transformation: transcultural classroom dialogues. New York: Palgrave/Macmillan.

KILOMBA, G. (2008). Memórias da plantação: episódios de racismo cotidiano. Rio de Janeiro: Cobogó, 2019.

KOHAN, W. (2019). Paulo Freire, mais do que nunca: uma biografia filosófica. Belo Horizonte, 2019.

KRAYNAK, J.; SMITH, K. (2009). Stage a Poetry Slam: Creating Performance Poetry Events-Insider Tips, Backstage Advice, and Lots of Examples (A Poetry Speaks Experience Book. Illinois: Sourcebooks.

KRENAK, A. (2020). O amanhã não está à venda. São Paulo: Companhia das Letras.

LIBERALI, F. C. (2020). Construir o inédito viável em meio à crise do coronavírus - Lições que aprendemos, vivemos e propomos. In: LiBERALI, F. C.; FUGA, V. P.; DIEGUES, U. C. C.; CARVALHO, M. P. (orgs.). Brincando em tempos de pandemia: brincando com um mundo possível. Campinas: Pontes. p. 13-21.

LI WEI (2011). Moment analysis and translanguaging space: discursive construction of identities by multilingual Chinese youth in Britain. Journal of Pragmatics, n. 43, p. 1222-1235.

LI WEI. (2018). Translanguaging as a Practical Theory of Language. Applied Linguistics, vol. 39, n.1, p. 9-3.

MAKONI, S.; PENNYCOOK, A. (eds.). (2007). Disinventing and Reconstituting Languages. Clevedon: Multilingual Matters, 2007.

MALDONADO-TORRES, N. (2018). Analítica da colonialidade e da decolonialidade: algumas dimensões básicas. In: BERNARDINO-COSTA, J.; MALDONATO-TORRES, N.; GROSFOGUEL, R. (Orgs.). Decolonialidade e pensamento afrodiaspórico. Belo Horizonte: Autêntica, p. 27-54.

MIGNOLO, W. (2000). Global Histories/Local Designs. Coloniality, Subaltern Knowledges and Border Thinking. New Jersey; Princeton University Press.

MATURANA, H.; VARELA, F. (1998). The three of knowledge. The biological roots of Human understanding. Boston/London: Shambhala.

MAZZAFERRO, G. (2018). Translanguaging as everyday practice. An introduction. In: Mazzaferro, Gerardo (ed.). Translanguaging as everyday practice. New York: Cham: Springer.

McKINNEY, C. (2017). Language and Power in Post-Colonial Schooling: Ideologies in Practice. London/New York: Routledge.

MEGALE, A.; LIBERALI, F. C. (2020). As implicações do conceito de patrimônio vivencial como uma alternativa para a educação multilíngue, Revista X, v.15, n.1, p. 55-74. Disponível em: < https://revistas.ufpr.br/revistax/article/view/69979/40692>. Acesso em 03 de nov. 2020. 
MENEZES DE SOUZA, L. M. T.; MARTINEZ, J. Z.; DINIZ DE FIGUEIREDO, E. H. (2019). Eu só posso me responsabilizar pelas minhas leituras, não pelas teorias que eu cito: entrevista com Lynn Mario Trindade Menezes de Souza (USP), Revista X, v. 14, n. 5, p. 5-21. Disponível em: https://revistas.ufpr.br/revistax/article/view/69230. Acesso em 25 jun. 2021.

MIGNOLO, W. (2017). Desafios decoloniais hoje. Epistemologias do Sul, Foz do Iguaçu/PR, v. 1, n. 1, p. 12-32, 2017.

MIGNOLO, W. (2000). Local Histories/Global Designs: Essays on the Coloniality of Power, Subaltern Knowledges and Border Thinking. Princeton: Princeton University Press.

MOITA LOPES, L. P. (2006). Por uma linguística aplicada indisciplinar. São Paulo: Parábola.

MOITA LOPES, L.P. (2010). Da aplicação da Linguística à Linguística Aplicada INdisciplinar. Disponível em: https://ufscdeutsch2010. files.wordpress.com/2010/10/nps156.pdf Acesso em: 21 Out 2021.

NASCIMENTO, E. A. (2018). O corpo deslizando sentidos: arte, protesto e discurso nas fronteiras com o social a partir das obras de Halter. In: OSORIO, E. M. R.; DI CAMARGO JR, I. (org.). Mikail Bakbtin: a arte como resposta responsável. São Carlos: Pedro e João Editores, p. 53-78.

NEVES, C. A. B. (2021a). Letramentos literários em travessia na Linguística Aplicada: ensino transgressor e aprendizagem subjetiva da literatura. In: LIMA, E. Linguística aplicada na Unicamp : travessias e perspectivas [livro eletrônico] / organização Érica Lima. - 1.ed. - Bauru, SP : Canal 6.

NEVES, C. A. B. (2021b). Poemar é preciso porque somos poesistência. In: Das ruas para as escolas, das escolas para as ruas: Slam Interescolar. São Paulo: LiteraRua, p. 8-11.

NORONHA, R. Surge et ambula. In: MENDONÇA, F. Literatura moçambicana: as dobras da escrita. Maputo: Ndjira, 2008, p. 144

PENNYCOOK, A. (2006). Uma Linguística Aplicada transgressiva. In: Moita Lopes, L.P. (org.), Por uma Linguística Aplicada INdisciplinar. São Paulo: Parábola..

PENNYCOOK, A (2017). Translanguaging and semiotic assemblages. International Journal of Multilingualism, v. 14, n. 3, p. $269-282$. Available at: <https://doi.org/10.1080/ 14790718.2017.1315810>. Access on: 15 Jan. 2020.

PEIRCE, C. (1955). Collected papers II. Philosophical writing of Peirce. New York: Dover.

POZA, L. (2017). Translanguaging: Definitions, implications, and further needs in burgeoning inquiry, Berkley Review of Education, v. 6, n. 2, p. 101-128. Disponível em: https://escholarship.org/uc/item/8k26h2tp. Access on: 10 nov. 2020

PONZIO, A. A concepção bakhtiniano do ato como dar um passo. In: BAKHTIN, M. M. (2009). Para uma filosofia do ato responsável. São Carlos: Pedro e João, 2017. p. 9-38.

ROCHA, C. H., MACIEL, R. F. (2015). Ensino de língua estrangeira como prática translíngue: articulações com teorias bakhtinianas. D.E.L.T.A., 31 (2), 411-445. DOI: https://doi.org/10.1590/0102-4450437081883001191.

ROCHA, C. H., MEGALE, A., H., (2021). Translinguagem e seus atravessamentos: dos entendimentos conceituais e das possibilidades para decolonizar a educação linguística contemporânea. D.E.L.T.A Preprint. Disponível em: https:// preprints.scielo.org/index.php/scielo/preprint/view/2733/4794 Acesso em: em 28 out. 2021.

ROJO, R. Letramentos múltiplos, escola e inclusão social. São Paulo: Parábola, 2009.

SANTOS, B. S. (2007). Para além do pensamento abissal: das linhas globais a uma ecologia de saberes. Revista Novos Estudos CEBRAP, São Paulo, n. 79, p. $71-94$.

SAMPAIO, M. C. H. (2019). A linguagem como experiência pensante e ensino: diálogos entre M. Bakhtin e M. Heidegger. In: BRAIT, B.; PISTORI, M. H. C.; FRANCELINO, P. F. (orgs.). Linguagem e conbecimento (Bakbtin, Volóchinov, Medviédev). Campinas: Pontes. p. 293-320. 
SEVERO, S.; ABDELHAY, A.; MAKONI, S. (2020). Translanguaging in the Global South, Scrutiny2, v. 2, n. 1, p. $104-109$. DOI: $10.1080 / 18125441.2020 .1851014$

SILVERSTEIN, M. (2003). Indexical order and the dialectics of sociolinguistic life, Language and Communication, n. 23, p. $193-229$.

SLAM DA GUILHERMINA (2020). Final Slam Interescolar - Ensino Médio. Slam Interescolar SP. (3:06). Disponível em: https:// www.youtube.com/watch?v=LdTTnbFvdqw Acesso em: 13 jul. 2021.

SOARES, E. V.; ALVES, A. A. Literatura e materialismo cultural: uma proposta de análise . Sociedade e Estado [online]. 2015, v. 30, n. 02 [Acessado 14 Julho 2021], pp. 371-388. Disponível em: < https://doi.org/10.1590/S0102-699220150002000006>. ISSN 0102-6992. https://doi.org/10.1590/S0102-699220150002000006.

SOBRAL, A. (2019). A filoosfia primeira de Bakbtin: Roteiro de leitura comentado. Campinas: Mercado de Letras.

SOUZA, A. L. S. (2016). Letramentos de Reexistência - Poesia, grafite, música, dança: Hip Hop. São Paulo: Parábola.

VARELA, F. (1999) Quatre phares pour l'avenir des sciences cognitives. Revue Théorie Littérature Enseignement 17, 7-21.

VOLÓCHINOV, V. (1929). Marxismo e filosofia da linguagem: problemas fundamentais do método sociológico na ciência da linguagem. Tradução de Sheila Grillo e Ekaterina Vólkova Américo. São Paulo: Editora 34, 2017.

WALSH, C. (2019). Gritos, gretas e semeaduras de vida: entreteceres do pedagógico e do colonial. In: Entre-linhas: educação, fenomenologia e insurgência popular / Sueli Ribeiro Mota Souza, Luciano Costa Santos, organizadores. - Salvador: EDUFBA, p. 93-120.

ZEGADA C., M. T. 2018. Bolívia: a democracia intercultural como síntese das diferenças. In: SANTOS, Boaventura de Sousa; MENDES, José Manuel (Orgs.). Demodiversidade: imaginar novas possibilidades democráticas. Belo Horizonte: Autêntica. p 459-480.

ZUMTHOR, P. (1990). Performance, recepção, leitura (2007). Trad. Jerusa Pires Ferreira e Suely Fenerich. [recurso eletrônico]. São Paulo: Ubu Editora, 2018.

Recebido: 14/7/2021

Aceito: 18/10/2021

Publicado: 26/10/2021 